\title{
Keruntuhan Teori Flat Earth Menurut Filsafat Islam dan Al-Quran
}

\author{
Tomi Apra Santosa1, Emayulia Sastria², Dharma Ferry ${ }^{3}$ \\ ${ }^{1}$ Magister Pendidikan Biologi, Universitas Negeri Padang \\ 2,3Pendidikan Biologi, Institut Agama Islam Negeri (IAIN) Kerinci \\ Email : santosatomiapra@gmail.com
}

\begin{abstract}
Abstrack
This research aims to know how to collapse the theory of flat Earth according to Islamic philosophy and Al-Quran. The research used is qualitative research with a literature study method, namely tracing journals, articles, books, Tafsir Al-Quran, and other sources that support, combine, analyze, and draw conclusions. The results of the study that the philosophy of Islam and the Qur'an argue in detail and detail that the theory of Flat Earth or flat earth is contrary to the thought of the figures of Islamic philosophy and Qur'anic verses. The Flat Earth theory is unreasonable and non-scientific.
\end{abstract}

Keywords : Flat Earth theory, Islamic philosophy, and Quran

\begin{abstract}
Abstrak
Penelitian ini bertujuan untuk mengetahui bagaimana keruntuhan teori flat earth menurut filsafat Islam dan Al-Quran. Penelitian yang digunakan adalah penelitian kualitatif dengan metode studi kepustakaan, yaitu menelusuri jurnal-jurnal, artikel, buku, tafsir Al-Quran, hadist, dan sumber lain yang mendukung, menggabungkan, menganalisa dan menarik kesimpulan. Hasil penelitian bahwa filsafat Islam dan AlQur'an membantah secara rinci dan detail bahwa teori Flat earth atau bumi datar bertentangan dengan pemikiran para tokoh filsafat Islam dan ayat-ayat Al-Qur'an. Teori flat earth tidak masuk akal dan bersifat non ilmiah.
\end{abstract}

Kata Kunci : Teori Flat Earth, Filsafat Islam, dan Al-Quran 


\section{PENDAHULUAN}

Manusia adalah Manusia adalah makhluk paling sempurna yang pernah diciptakan oleh Alla SWT (Rizal 2017). Manusia memiliki akal pikiran yang digunakan untuk berpikir tentang ilmu pengetahuan. Dalam Islam semua ilmu pentahuan bersumber dari Al-Qur'an. AlQuran adalah kalam Allah yang diturunkan kepada nabi Muhammad saw melalui Malaikat Jibril dan jadikan pedoman untuk meraih kebahagian dunia dan akhirat. Selain Al-Quran ada lagi sumber lain, misalnya filsafat. Filsafat adalah ilmu yang membahas segala sesuatu yang ada, dengan cara berpikir teliti, cermat, menyeluruh, bebas, dan mendalam untuk mendapatkan hakikat yang dipakai sebagai pegangan hidup manusia agar tercapai kehidupan yang damai dan sejahtera (Muis 2012). Manusia menggunakan pikiran untuk memikir segala bentuk fenomena yang terjadi di alam semesta. Alam semesta adalah realitas yang dihadapi oleh manusia, yang sampai kini baru sebagian kecil saja yang dapat diketahui dan diungkap oleh manusia (Madaniyah and Maunah 2019). Banyak para ilmuwan-ilmuwan yang masih tertarik untuk mengkaji seluk beluk alam semesta, seperti bulan, matahari, bumi, planet dan lain sebagainya. Bumi meruapakan salah satu planet dari susunan tatasurya yang dihuni oleh milyaran makhluk hidup.

Bumi mempunyai bentuk yang unik dibandingkan dengan planet yang lain. Maka dengan itu banyak ilmuwan islam dan barat mengkaji mengenai bentuk dan ukuran bumi, misalnya Ibnu Al-Shatir, Ibnu Rusyd, Al-Biruni, Al-Khawarizmi, AlGhazali, Galileo, Phytagoras, Aristolelas, Nicolas Copernicus, Isaac Newto. Para ilmuwan muslim jauh sebelum Galileo Galilei sudah menyatakan bahwa bumi berbentuk bulat, seperti Ibnu Al-Shatir, Ibn Rusyd, Al-Biruni dan Al-Khawarizmi. Akan tetapi, ilmuwan yang populer menyatakan bumi bulat, yakni Galileo
Galilei dan Nicolas Copernicus(Boden and Epstein 2011). Di India bumi berbentuk bulat sudah akui dalam Shatapatha brahmana dan Aitareya Brahmana (Mubarok 2019). Pada 2018 seorang astronot kebangsaan Uni Emirat Arab bernama Hazza Al Mansouri berada di stasiun luar angkasa Internasional Space Station (ISS) menyatakan bahwa bumi berbentuk bulat bukan datar.

Para filsuf yunani seperti Plato dan Aristoles juga menyatakan bahwa bumi bulat (Sitanggung 2020). Pada tahun 2013 yang lalu banyak muncul video teori bumi datar atau flat earth di situs Youtube yang dibuat oleh para penganut flat earth (Afaq et al. 2019). Teori flat earth ini dipelopori oleh Samuel Rowbhotam tahun 1850. Pada saat sekarang ini Teori flat earth telah mengalami kebangkitan yang cukup pesat. Berdasarkan survei $2 \%$ dari penduduk Amerika Serikat telah mempercayai bumi itu datar (Prastiwi 2019). Menurut mereka bahwa pemeritah dan ilmuwan telah berbohong kepada publik dianggap menyebarkan data palsu (Prastiwi 2019). Teori flat earth juga dianggap telah mempengaruhi penyebaran informasi-informasi sains ilmiah di dunia dan pikiran manusia yang berabad tentang bumi bulat (Bartlett 2013, Mohammed 2019). Berdasarkan latar belakang diatas, penelitian ini bertujuan untuk memaparkan bagaimana keruntuhan teori flat earth menurut filsuf Islam dan Al-Quran.

\section{METODE}

Penelitian ini adalah penelitian kualitatif, yaitu suatu proses dari berbagai langkah yang melibatkan peneliti, paradigma teoritis dan interpretatif, strategi penelitian, metode pengumpulan data dan analisis data empiris, maupun pengembangan interpretasi dan pemaparan (Saebani 2008).

Dengan menggunakan metode studi pustaka (library research). Studi pustaka 
adalah serangkaian kegiatan yang berkenaan dengan pengumpulan data dan pustaka, membaca, mencatat serta mengolah bahan penelitian (Zed 2003). Sumber data berasal dari literatur berupa jurnal, buku, tafsir, hadist dan sumber lain yang relevan.

\section{HASIL DAN PEMBAHASAN}

\section{Teori Flat Earth}

Teori flat earth muncul pada abad pertengahan tepatnya tahun 1850 yang pelopori oleh ilmuwan inggris bernama Samuel Rowbhotam. Ia menerbitkan sebuah buku Zetetic Astronomy: Earth Not a Globe. Dalam bukunya menyatakan bahwa bumi itu datar yang berpusat di kutub utara dimana bagian tepinya berbatas dengan tembok es yang sangat besar. Dengan demikian, muncul teori Flat earth yang menyatakan bahwa bumi berbentuk datar. Flat eart disebutkan sebuah organisasi yang didirikan oleh Samuel Sheton pada tahun 1956 (Hamidiyah 2017). Setelah kematian Samuel Sheton organisasi ini dipimpin oleh Charles $\mathrm{K}$. Johson yang berbasis di California, Amerika Serikat. Pada tahun 2001 Charles $\mathrm{K}$. Johson meninggal dunia dan digantikan oleh Daniel Sheton dengan nama baru, yakni flat earth society.

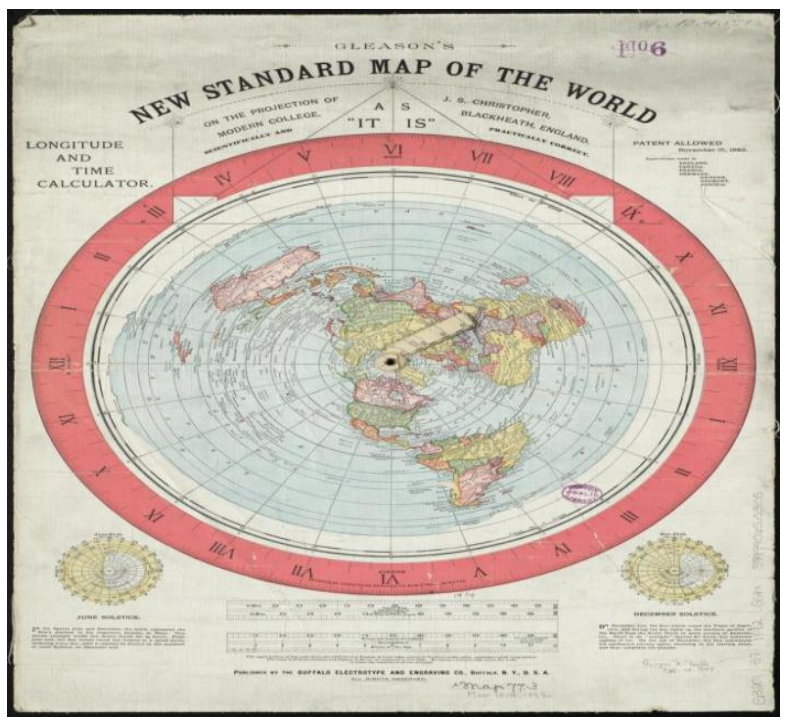

Gambar 1. Flat earth atau bumi datar

\section{Flat Earth Menurut Filsafat Islam}

Filsafat adalah studi secara kritis mengenai masalah-masalah yang timbul dalam kehidupan manusia dan merupakan alat dalam mencari jalan keluar yang terbaik agar dapat mengatasi semua permasalahan hidup dan kehidupan yang dihadapi (Idi 2011). Menurut filsuf Islam Al-Kindi filsafat adalah pengetahuan kebenaran yang pertama sebab dari segala kebenaran (Salam 2012). Menurut Al-Farabi Filsafat adalah ilmu pengathuan tentang hakikat bagaimana alam maujud yang sebenarnya (Surajiyo 2005). Dengan demikian filsafat adalah pengetahuan yang bertujuan untuk mencari hakika sebenar segala sesuatu.

Dalam filsafat Islam juga membahas tentang kebenaran suatu teori. Teori merupakan sebuah dalil yang diperoleh dari pengkajian ilmiah. Filsafat Islam juga telah menerang hakikat bentuk bumi. Salah satu filsuf Islam bernama Al-Biruni mengkritisi tentang kelompok yang mendukung teori bumi datar (flat earth). Menurutnya, jika bumi datar niscaya tidak akan terjadi siang dan malam, baik di musim dingin maupun musim panas serta tidak terjadi penampakan planet. $\mathrm{Al}$ Biruni memberikan dua argumen yaitu Pertama, argumen gerhana Bulan dan gerhana Matahari. Gerhana Bulan adalah keadaan dimana piringan Bulan terhalang sinar Matahari sehingga piringan Bulan terjadi secara bersamaan waktunya bagi penduduk Bumi yang dapat melihat Bulan. Sementara gerhana Matahari hanya terhalang penglihatan dari sinar Matahari sehinggah proses gerhana Matahari tidak sama waktu dan durasinya jika dilihat oleh penduduk Bumi. Dari hasil tersebut tidak bisa dikatakan bahwa bumi bulat atau Flat earth(Alwin Juli Rahkmayadi 2019). Kedua, berdasarkan pengamatan Bumi itu tidak datar. Hasil pengamatan mengenai dataran Bumi yang tidak sama, ada yang tinggi dan ada yang rendah, 
menandakan bahwa bentuk Bumi adalah bulat (Alwin Juli Rahkmayadi 2019).

Filsuf Islam lainnya adalah Ibnu Khaldun dalam kitabnya berjudul " Muqaddimah" menyatakan bahwa bumi berbentuk seperti bola. Fakta tersebut dapat kita lihat pada Globe yang dibuat pada tahun 830 SM yang dirancang oleh Musa Al-Khawarizmi yang merupakan filsuf yang ahli dibidang matematika, Astronomi dan geografi(Walid 2014). Pada masa Islamisasi sains muncul sosok filsuf Islam yang paling terkenal bernama Abu Abdullah Muhammad Ibnu Umar Bin Al-Husin At-Taimi Al Bakri At-Tabaristani Fakhruddin Ar-Razi beliau lahir di Bandar Rai, Iran sebuah daerah berdekatan dengan Teheran pada tahun $544 \mathrm{H}$ (Handrianto 2010). Ar-Razi adalah ulama yang saintis. Hal itu dapat dibuktikan dengan karya ilmiahnya yang sangat banyak, baik masalah sains maupun masalah agama. Ia telah menulis 6 karya dalam ilmu tafsir, 20 karya dalam ilmu kalam, 9 karya dalam bidang Filsafat, 6 karya dalam ilmu filsafat dan Kalam, 5 karya dalam bidang bidang logika, 2 karya bidang Matematika, 6 karya bidang ilmu kedokteran, 9 karya bidang ilmu Syariah, 4 karya dalam bidang Sastra, dan masih puluhan lagi karyanya dalam bidang ilmu pengetahuan (Handrianto 2010). Ar-Razi merupakan orang pertama kali menjadi logika sebagai ilmu tersendiri. Dalam kitabnya Ar-Razi menyatakan bahwa bumi itu berbentuk bulat dan bumi berputar mengeilingi matahari.

Dalam filsafat Islam bumi berbentuk bulat juga dilontarkan oleh Al-Farabi. Dia seoarang filsuf dan ahli musik. Menurutnya penciptaan alam ini terjadi secara emanasi atau pancaran Tuhan (al faidh al ilahiy) melalui daya akal yang tunggal dan esa, kekal, abadi yang disebut akal murni, kemudian menjadi alam raya yang beraneka ragam, proses emanasi berhenti pada akal ke sepuluh yang dinamai akal fa'al, pada akal ke sepuluh ini tidak lagi ber-emanasi karena daya kekuatan akalnya melemah (Wiyono et al.
2016). Dari penjelasan bahwa alam semesta termasuk bumi diciptakan secara langsung oleh Allah swt atau lebih dikenal dengan emanasi. Akan tetapi, Al-Farabi tidak menyatakan secara detail tentang bentuk. Boleh jadi secara emanasi atau pancaran tuhan mengatakan bumi itu bulat sesuai dengan Q.S. Ali Imran ayat 27 dan Al-Fathir ayat 13.

\section{Flat Earth Menurut Al-Quran}

Manusia adalah mahkluk Allah yang diberi akal dan pikiran yang digunakan untuk berpikir. Pikiran atau logika yang dianugerahkan oleh Allah diperintah untuk melihat tanda-tanda kebesaran Allah. Salah satu tanda-tanda kebesaran Allah adalah Bumi. Bumi adalah satu satunya planet dalam sistem tata surya yang dapat dihuni oleh manusia. Al-Quran merupakan kitab suci umat Islam yang dijadikan rujukan utama dalam pengambilan hukum Islam atau keilmuan yang berkaitan dengan keislaman atau segala sesuatu yang berkaitan dengan seluruh isi alam (Asnajib 2020). Al-Quran sebagai penyikap tabir rahasia yang sangat dalam dan penting, serta kebenaranya dapat dibuktikan secara ilmiah.

Menurut Margoliouth Al-Quran itu menempati kedudukan yang maha penting dalam barisan agama-agama yang besar didunia (Zuhdi 2011). Al-Quran merupakan sumber ilmu pengetahuan, seperti ilmu astronomi. Geologi, geografi, biologi, fisika dan kimia. Dalam ilmu astronomi dan geologi mengkaji tentang berbagai fenomena tentang matahari, bulan, bintang termasuk di dalamnya bumi. Sebelum ini, manusia beranggapan bahwa bentuk permukaan bumi itu datar Flat earht, seperti hamparan serta langit sebagai atap. Mereka berependapat bahwa bintang-bintang merupakan pakupaku yang terbuat dari perak dan tersusun di kubah langit atau lampulampu tergantung di angkasa (Zuhdi 2011). Semua pendapat tersebut dipatahkan oleh Al-Quran empat belas 
adab yang lalu. Di dalam Al-Quran sudah diterang bahwa bumi berbentuk bulat.

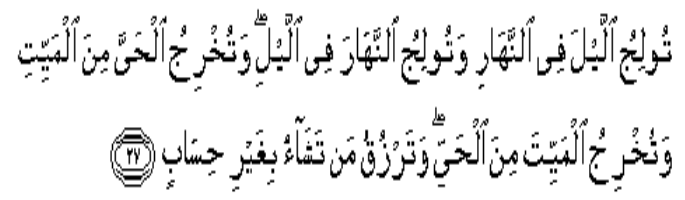

Artinya: Engkau masukan malam ke dalam siang (lebih lama malam). Dan masukan siang ke dalam malam (lebih lama siang). Engkau keluarkan yang hidup dari yang mati dan engkau keluarkan yang mati dari yang hidup dan Engkau beri rezeki siapa yang Engkau kehendaki tang terhitung (Q.S. Ali Imran: 27)
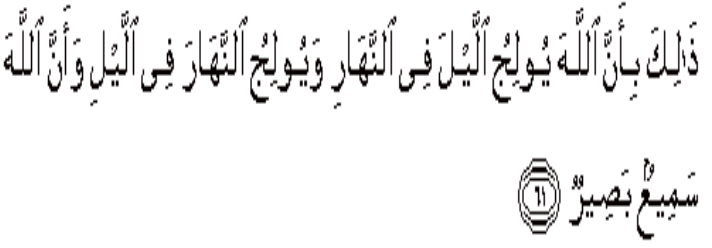

Artinya: Demikian itu, karena Allah masukan malam ke dalam siang dan memasukan siang kedalam malam dan sesungguhnya Allah Maha Mendengar lagi Maha Melihat. (Q.S Al-Hajj: 61)

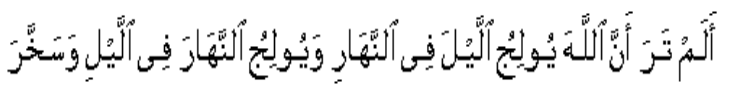

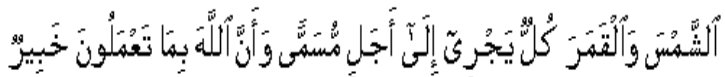

Artinya: Tidaklah engkau melihat, bahwa Allah memasukan malam pada siang dan memasukan siang pada malam dan menundukan matahari dan bulan (untukmu). Masing -masing beredar, hingga waktu yang ditentukan. Sesungguhnya Alla Maha Mengeatahui apa yang kamu kerjakan. (Q.S. Luqman: 29)

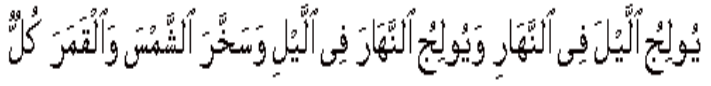

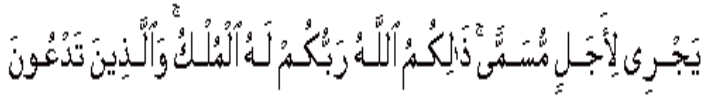

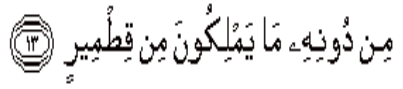

Artinya: Dia memasukan malam ke dalam siang dan memasukan siang ke dalam malam dan Dia menundukan matahari dan bulan (untuk kepentingan mu), masing-masing berlari (beredar), menurut waktu yang ditentukan. Itulah Allah, Tuhanmu baginya semua kerajaan. Orang -orang yang kamu sembah selain Allah, tidak mempunyai apa-apa walaupun sebesar kulit tipispun (sedikitpun). (Q.S.Faathir: 13)

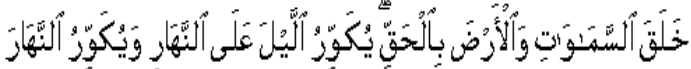

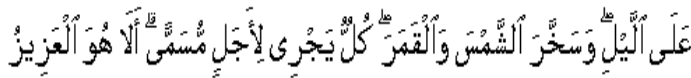

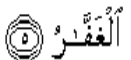

Artinya: Dia menciptakan langit dan bumi dengan sebenarnya. Dia memutarkan (memasukan) malam kepada siang dan memutar siang kepada malam dan menundukan mataharidan bulan (untukmu) masing-masing berlari (beredar) sampai waktu yang telah ditentukan. Ingatlah, Dia Maha Perkasa lagi Maha Pengampun. (Q.S Zumar: 5)

Dari ayat diatas dapat kita katakan bahwa Al-Quran sudah lama menyatakan bahwa bumi bulat. Selain itu para Ulama telah menafsir kata "Yukawiru" artinya melilitkan, yaitu melilikan sesuatu yang bulat. Menurut seorang ulama dari Saudi Arabia yang bernama Syaikh Utsaimi, mengatakan bahwa bumi bulat sudah jelas dterangkan dalam Quran yakni Az-Zumar ayat 5. Menurutnya Takwir artinya melilitkan atau memutar, contohnya memilitkan sorban diatas kepada. Dengan demikian siang dan malam terjadi tentunya bumi berputar pada porosnya yang lebih dikenal berotasi.

Bumi berbrntuk bulat akan terjadi siang dan malam setiap daerah mengalami pergiliran siang dan malam serta terjadi perganitian waktu. Menurut Ahli tafsir Indonesia yang bernama Mahmud Yunus menafsir surat Al-Hajj ayat 61, dia menyatakan Allah memasukan malam pada siang, artinya malam itu lebih 
panjang dari siang, dan memasukkan siang pada malam, artinya siang itu lebih panjang daripada malam. Hal ini dapat dibuktikan dengan sejelas-jelasnya pada negeri-negeri khatulistiwa, seperti Mesir, Eropa, Jepang dan Indonesia, misalnya pada sebagian negara malam itu 14 jam dan lamanya siang 10 jam. Maka malam lebih panjang daripada siang, yakni waktu musim dingin. Akan tetapi, musim panas sebaliknya, siangnay 14 jam dan malamnya 10 jam(Mahmud Yunus 2015). Hal ini menyatakan bahwa bumi itu bulat tidak datar atau Flat earth. Semua buktibukti yang telah dijelaskan dalam AlQuran telah keruntuhkan pemikiran kaum penganut teori Flat earth atau bumi datar. Hal ini juga membuktikan bahwa Al-Quran sumber ilmu pengetahuan yang kebenarannya dapat dibuktikan secara ilmiah.

\section{DAFTAR PUSTAKA}

Afaq, A. L.,. 2019. “Telaah Kritis Gerhana Flat Earth Dalam Perspektif Teori Kebenaran Pragmatis." JurnaL IImu Falak Dan Astranomi 1(2):157-74.

Alwin Juli Rahkmayadi. 2019. Khazanah Astronomi Islam Abad Pertengahan. Purwokerto: UM Purwokerto Press.

Asnajib, $\quad$ Muhammad. 2020. "PERKEMBANGAN PARADIGMA PENAFSIRAN KONTEMPORER DI INDONESIA : Studi Kitab Tafsir AtTanwir." Diya" Al-Afkar: Jurnal Studi Al-Quran Dan Al-Hadist 8:4964.

Bartlett, Albert A. 2013. "THE EXPONENTIAL FUNCTION , XI : ( 1 ) THE NEW FLAT EARTH SOCIETY." (1):1-11.

Boden, Rebecca, and Debbie Epstein. 2011. "A Flat Earth Society? Imagining Academic Freedom." 3:495.

Hamidiyah, Hafna. 2017. “Analisis
Penafsiran Lafadz 'Firo>shan' Dalam Al Qur'an Dengan Konspirasi Flat Earth)." Skripsi 98.

Handrianto, Budi. 2010. Islamisasi Sains. Jakarta: Al-Kausar.

Idi, Jalaludin dan Abdullah. 2011. Filsafat Pendidikan. Jakarta: Rajawali Press.

Madaniyah, Jurnal, and Siti Maunah. 2019. "HAKIKAT ALAM SEMESTA MENURUT FILSUF ISLAM Siti Maunah 1." Jurnal Madaniyah 9:1-21.

Mahmud Yunus. 2015. Tafsir Quran Karim. Jakarta: PT. Mahmud Yunus Wa Dzurriyah.

Mubarok, H. Aliyah. 2019. "Islamic Students Understanding about the Center of the Earth in Science and Islam Perspective." 2(November):713.

Muis, Soegiono \&. Tamsil. 2012. Filsafat Pendidikan. Bandung: Remaja Rosdakarya.

Prastiwi, Vicki Dian. 2019. "Description of Students ' Scientific Literacy Competencies on the Scientific Issue Of." Anatolian Journal of Education 4(2):31-38.

Rizal, Syamsul. 2017. "MELACAK TERMINOLOGI MANUSIA DALAM ALQURAN" Jurnal At-Tibyan 2(2).

Saebani, Beni Ahmad. 2008. Metode Penelitian. Bandung: Pustaka Setia.

Salam, BUrhannudin. 2012. Pengantar Filsafat. Bandung: Bumi Aksara.

Sitanggung, Asigor P. 2020. "Pengaruh Kosmologi Bumi Datar Dalam Eskatologi Alkitab." Jurnal:Teologi Dan Pendidikan Kristen Kontektual 3(1):90-101.

Surajiyo. 2005. Ilmu Filsafat. Jakarta: Bumi Aksara. 
Walid, Abdul. 2014. Menguak Fakta Sejarah Penemuan Sains Dan Teknologi Islam Yang Diklaim Barat.

Wiyono, M., Sekolah Pascasarjana, Univeristas Islam, and Negeri Syarif. 2016. "Pemikiran Filsafat Al-Farabi." Substantia 18(April):67-80.

Zed. 20023. Metode Penelitian Kepustakaan. Jakarta: Yayasan Obor Indonesia.

Zuhdi, Ahamd. 2011. Studi Tentang Pemahaman Islam. Sungai Penuh: Stain Press. 